Vol. 1 No. 2 (2018)

\title{
KOMUNIKASI POLITIK SABILULUNGAN RAKSA DESA DI KABUPATEN BANDUNG
}

\author{
Vera Hermawan \\ Program Studi Ilmu Komunikasi FISIP Universitas Pasundan \\ verahermawan@unpas.ac.id
}

\begin{abstract}
This paper discusses about the Sabilulungan Raksa Desa movement which is the philosophy and principle of Dadang Naser Regent and the bureaucracy in Bandung Regency in carrying out their duties and authority. This basis aims to foster a spirit of togetherness and mutual cooperation between the local government and the community. The target of the Sabilulungan Raksa Desa movement is, rutilahu or uninhabitable houses, water, latrines, garbage and nature. Constraints in implementing the Sabilulungan Raksa Desa include political resistance, social constraints and ceremonial culture. The management of media issues is carried out conventionally through press conferences, media relations and descending together with community leaders.
\end{abstract}

\section{Keyword: Political Communication, Bandung, Sabilulungan Raksa Desa}

\begin{abstract}
Abstrak
Tulisan ini membahas tentang, Gerakan sabilulungan raksa desa yang merupakan filosofi dan prinsip Bupati Dadang Naser dan birokrasi di Kabupaten Bandung dalam melaksanakan tugas dan wewenangnya. Dasar ini bertujuan, menumbuhkan semangat kebersamaan dan gotong royong antara pemerintah daerah dengan masyarakat. Sasaran gerakan sabilulungan raksa desa yaitu, rutilahu atau rumah tidak layak huni, air, kakus, sampah dan alam. Kendala implementasi gerakan sabilulungan raksa desa antaralain, resistensi politik, kendala sosial dan budaya seremonial. Pengelolaan media isu dilaksanakan secara konvensional melalui konferensi pers, silaturahmi media dan urun rumbuk bersama tokoh masyarakat.
\end{abstract}

Kata Kunci: Komunikasi Politik, Kabupaten Bandung, Sabilulungan Raksa Desa

\section{PENDAHULUAN}

Bupati Kabupaten Bandung Dadang Naser sebagai komunikator di wilayahnya menjalankan tugas Kepala Daerah dalam sebuah program kebijakan yaitu Sabilulungan Raksa Desa, dimana keberhasilan dari program itu menjadi pesan dalam komunikasi politik yang dikelola bersama para realawan Sabilulungan. Tim relawan yang tergabung dalam sabilulungan raksa desa dalam komunikasi politik, dapat dikatakan sebagai komunikator politik. Selain Dadang Naser sendiri yang menjadi icon atau komunikator utama dalam komunikasi politik dalam rangka menjaga popularitas dan elektabilitas Dadang Naser.

Menurut Dan Nimmo (2005), ada beberapa karakteristik komunikator politik yaitu berpendidikan tinggi melebihi rata-rata populasi, memiliki pendapatan dan status sosial yang lebih 
tinggi, terlibat aktif dalam politik, memiliki kepercayaan politik, dan berpengaruh besar terhadap pembuatan kebijakan. Dalam konteks ini peneliti berasumsi orang-orang yang menjadi penggerak dalam program sabilulungan raksa desa, merupakan orang-orang yang memenuhi karakteristik dari komunikator politik yang dijelaskan oleh Dan Nimmo.

Dadang Naser berdasarkan claim para relawan sabilulungan merupakan figur yang mampu mengoptimalkan isuisu atas permasalahan yang ada di pedesaan. Kondisi ini peneliti mengasumsikan karena meningkatnya popularitas Dadang Naser melalui berbagai pemberitaan di media massa, sangat signifikan dalam menunjukkan program-program dan prestasinya, untuk kepentingan masyarakat di Kabupaten Bandung.

Peneliti mencermati apa yang telah dilakukan relawan sabilulungan sudah sesuai dalam penggunaan media komunikasi politik. Menurut Nimmo (dalam Cangara, 2009:22) menjelaskan mengenai unsur-unsur sebuah komunikasi politik diantaranya komunikator politik, pesan politik, saluran atau media politik, sasaran atau target politik, dan efek komunikasi politik. Tim Sabilulungan menyatakan Dadang Naser dalam komunikasi politiknya sudah memenuhi standar apa yang dikatakan Nimmo.

Dadang Naser menjadi komunikator politik senantiasa menggunakan beberapa hal, diantaranya ceramah atau pidato dari para ulama, aktifis buruh, opinion leader dari organisasi massa, Organisasi Kepemudaan, bahkan para relawan sabilulungan sebagai komunikator politik sekaligus pendukung dalam menyampaikan beberapa pesan politik, untuk mengajak masyarakat dalam membangun Kabupaten Bandung, melalui program unggulan yakni Sabilulungan Raksa Desa.

\section{Komunikasi Politik Gerakan Sabilulungan Raksa Desa}

Gerakan sabilulungan raksa desa merupakan gerakan yang diinisiasi Dadang Naser berserta pemerintah daerah kepada masyarakat di Kabupaten Bandung. Gerakan ini ditujukan untuk menumbuhkan dan menjaga spirit kebersamaan, gotong royong, dan hidup beriringan dalam kehidupan sehari-hari. Kebersamaan dan gotong royong dalam tindakannya, baik dalam urusan pembangunan fisik maupun pembangunan psikis.

Pengambilan istilah sabilulungan memiliki alasan yang sederhana, yaitu ingin melestarikan budaya dan tradisi bahasa Sunda. Karena sabilulungan merupakan filosofi Sunda, dan memang sengaja diambil dari istilah Sunda agar lebih dekat, akrab, dan mudah dipahami masyarakat.

Kata sabilulungan di kalangan masyarakat lanjut usia sudah begitu akrab dan populer. Pasalnya dulu pernah ada lagu yang berjudul sabilulungan, karya yang dibuat oleh seniman sunda Mang Koko. Lagu ini sampai sekarang masuk kategori lagu yang fenomenal. Lagu ini juga memiliki nilai kebersamaan dan membangkitkan semangat jiwa orang Sunda sebagai gambaran hidup sehari-hari, yaitu hidup rukun sauyunan dengan melakukan kegiatan yang ikhlas (Sungkawa, 2013:11).

Kondisi masyarakat Kabupaten Bandung berdasarkan asumsi peneliti terlihat apatis terhadap sesama, nilainilai kebersamaan, gotong royong yang mulai hilang, bukanlah asumsi sepihak dengan penilaian yang subjektif. Melihat kenyataan di masyarakat, 
seiring waktu perkembangan zaman dengan semakin banyaknya informasi yang bisa diakses, telah membawa perubahan-perubahan masyarakat. Mulai dari perubahan pola pikir, tindakan, life stlye sampai pada prinsip dalam kehidupan sehari-hari. Masyarakat mulai asyik sendiri dengan hiburan yang bisa ditentukan di akses sendiri.

Perubahan pola pikir masyarakat itu merupakan hal negatif, sehingga pemerintah daerah melalui Sabilulungan pada periode pertama Dadang Naser menjadi bupati Kabupaten Bandung, memperkenalkan filosofi sabilulungan dalam membangun Kabupaten Bandung secara umum, namun pada sabilulungan raksa desa, selain ada penambahan istilah juga memperinci target atau tujuan yang ingin diraih dalam masa kepemimpinan yang kedua Dadang Naser.

Sabililungan raksa desa menurut

Berger dan Luckman merupakan realitas subyektif, yaitu realitas bagaimana pemerintah menginginkan agar nilai-nilai gotong royong, persaudaraan, persatuan dan kesatuan kembali hadir di tengah-tengah masyarakat Kabupaten Bandung yang diupayakan dalam program sabilulungan raksa desa.

Dadang Naser menyadari keberadaan dan posisinya yang mayoritas berbahasa Sunda, keturunan Sunda, dan sebagian besar penduduknya di pedesaan, maka fokus pembangunan itu adalah pada peningkatan pedesaan. Jadi, menurut pandangan Bungin dalam teori konstruksi sosialnya, dikaitkan dengan sabilulungan raksa desa ini merupakan program yang tidak berlangsung pada ruang hampa, tetapi sarat dengan sejumlah kepentingan. Terutama kepentingan dari Bupati Dadang Naser dalam rangka mensukseskan komunikasi politik pada sektor pembangunan di Kabupaten Bandung. Namun permasalahannya sabilulungan raksa desa belum menjadi habits atau kebiasaan dari masyarakat Kabupaten Bandung.

Pemahaman raksa dalam program sabilulungan raksa desa merupakan akronim dari $\mathrm{R}$ itu untuk Rutilahu (rumah tidak layak huni) yang akan dibantu sehingga secara perlahan tidak ada lagi rumah yang tidak layak dihuni oleh masyarakat Kabupaten Bandung. Implementasi dari Rutilahu dilaksanakannya 'bedah kampung' kepada 53 Kepala Keluarga di kampung Cilodong, Kecamatan Paseh dan perbaikan 1000 unit rumah pertahun.

Kemudian A itu adalah air yang harus dimanfaatkan sebaik mungkin dan dipergunakan sebaik-baiknya, sehingga air tidak tercemar, tetap sehat dan layak untuk dikonsumsi. Aktifitas kegitan itu dengan memberikan bantuan sarana air bersih dan bak penampungan terhadap 10 kecamatan di kabupaten Bandung; Kemudian $\mathrm{K}$ adalah kakus yang merupakan MCK. Karena bagaimana pun juga masih banyak masyarakat Kabupaten Bandung yang BAB sembarangan dan tidak tersedianya fasilitas yang memadai untuk MCK.

Kemudian untuk $\mathrm{S}$ adalah sampah. Mengenai sampah di kabupaten Bandung dijadikan prioritas dalam penanganannya. Karena sampah kalau dibiarkan bisa menjadi masalah yang besar. Dan sampah ini menjadi bagian yang sulit untuk ditangani. Sehingga pemerintah daerah melalui Dinas Lingkungan Hidup melaksanakan program Zero to Waste artinya menerapkan kesadaran masyarakat terhadap kebersihan dan membagi sampah menjadi beberapa bagian agar bermanfaat bahkan menghasilkan keuntungan financial. 
Terakhir adalah A yaitu alam. Keberadaan alam Kabupaten Bandung memiliki luas yang berlimpah. Sebagian besar sumber pendapatan daerah dan kekayaan daerahnya adalah alam yang indah, asri dan memiliki potensi wisata. Masyarakat Kabupaten Bandung memiliki pendapatan dari alam sekitar melalui program Leweung Sabilulungan, dimana lahan milik pemerintah bahkan perhutani di kelola oleh masyarakat yang ditanami pohon produksi, bahkan dimanfaatkan oleh wisatawan dari luar daerah untuk menghirup udara segar dan liburan pada alam terbuka khususnya di akhir pekan. Penjelasan program Raksa Desa dalam model berikut ini:

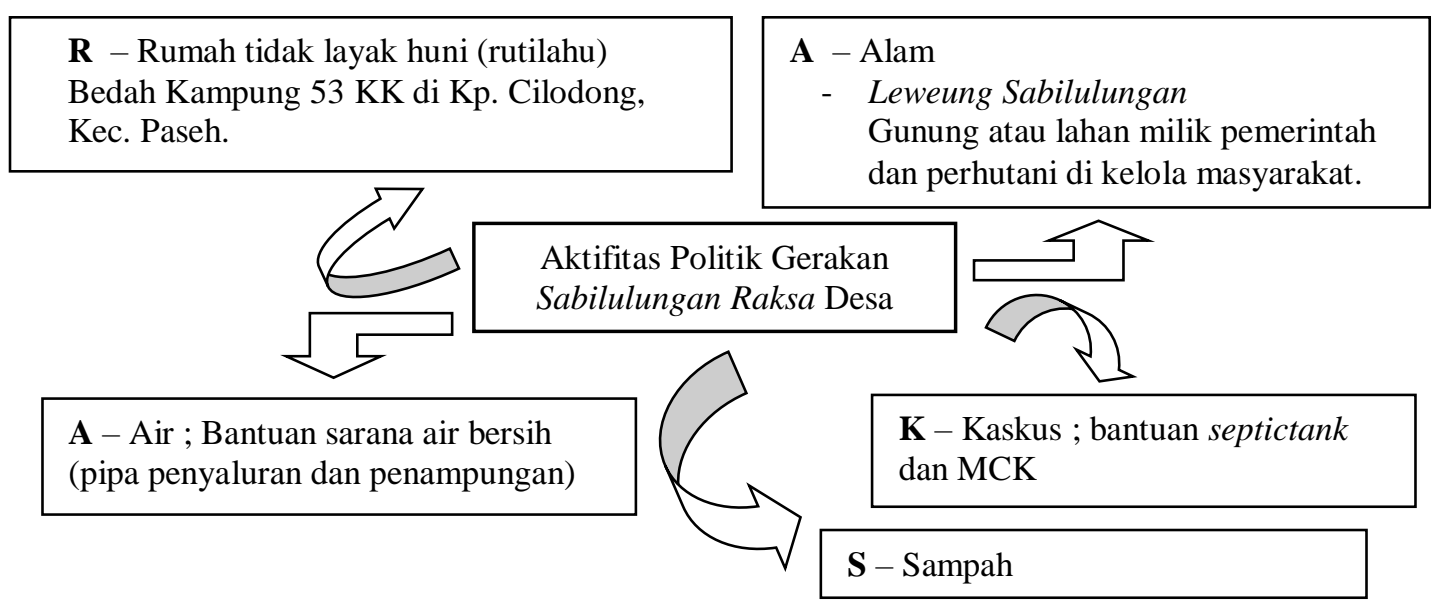

Sumber : Data olahan hasil penelitian

Gambar 1.

Model Gerakan Sabilulungan Raksa Desa di Kabupaten Bandung

Gerakan sabilulungan raksa desa merupakan aktifitas politik pada model diatas, merupakan strategi pemasaran politik yang dilakukan Dadang Naser beserta tim relawannya. Pemasaran politik pra dan pasca pilkada di Kabupaten Bandung, dalam rangka mempertahankan eksistensi politiknya. Menurut Bruce I. Newman dan Richard M. Perloff bahwa: "Pemasaran politik sebagai aplikasi prinsip-prinsip pemasaran dalam kampanye politik yang beraneka ragam individu, organisasi, prosedur-prosedur, dan melibatkan analisis, pengembangan, eksekusi, dan strategi manajemen kampanye oleh kandidat, partai politik, pemerintah, pelobi, kelompokkelompok tertentu yang bisa digunakan untuk mengarahkan opini publik terhadap ideologi mereka (dalam Cangara, 2016: 24)".

Berdasarkan pada penjelasan dari Bruce I. Newman dan Richard M. Perloff di atas bahwa Dadang Naser dan tim relawan sabilulungan raksa desa, sudah melakukan pemasaran poliitk dan mengapikasikan prinsip-prinsip pemasaran dalam kampanye politiknya dengan melibatkan partai politik, pemerintah, pelobi dan kelompok tertentu sehingga benar-benar terbangun opini publik mengenai keberhasilan dan kelayakan Dadang Naser untu menjadi bupati kembali di Kabupaten Bandung. Tidak hanya itu, popularitas Dadang Naser pada periode kedua semakin meningkat, program-programnya 
dirasakan benar-benar bermanfaat untuk masyarakat di Kabupaten Bandung.

$$
\text { Melalui konsep sabilulungan }
$$

raksa desa, Dadang Naser telah melakukan aktivitas politik, yaitu menyebarluaskan informasi tentang program yang dilakukan oleh aktor politik atau komunikator, dalam hal ini tim sukses, bupati, tim relawan sabilulungan, dinas terkait, SKPD, dan lain sebagainya melalui saluran-saluran komunikasi tertentu yang ditujukan kepada segmen atau sasaran tertentu, dengan tujuan mengubah wawasan, pengetahuan, sikap dan perilaku para calon pemilih atau masyarakat.

Aktivitas politik atau pemasaran politik yang dilakukan Dadang Naser memaksimalkan kombinasi elemen terbaik, dengan menggunakan teknologi komuniksi serta keterampilan pemasaran. Karena tim relawan sabilulungan raksa desa telah memenuhi sebuah proses pemasaran politik, yang setidaknya digerakkan oleh empat elemen utama, yaitu (Cangara, 2016: 241):

1. Produk atau kemasan yang diproduksi oleh unit yang dipasarkan, guna memenuhi kebutuhan. Produk disini sudah jelas, yaitu tanda gambar, cita-cita atau visi, program yang semuanya terangkum dalam istilah sabilulungan raksa desa.

2. Tempat. dalam konteks komunikasi politik, tempat sering diasosiasikan dengan istilah ruang publik (public sphere) seperti media massa atau ruang reklame di tempat-tempat strategis, public figure atau tokoh masyarakat yang ikut membantu menyebarluaskan isu dan program sabilulungan raksa desa.

3. Harga. Harga disini ialah maksudnya partai politik. Bagaimana pun juga Dadang Naser meskipun berangkat dari independen untuk maju pada pemilihan bupati untuk kedua kalinya, namun tetap Dadang Naser merupakan kader dari Partai Golongan Karya atau golkar yang menjadi partai pendukung dan mengantarkannya untuk kembali menjadi orang nomor satu di Kabupaten Bandung.

4. Promosi. Promosi maksudnya ialah usaha yang dilakukan untuk menarik perhatian orang, melalui teknikteknik komunikasi yang efektif. Dalam konteks komunikasi politik, promosi sering kali dihubungkan dengan istilah kampanye. Promosi atau kampanye memegang peranan penting, bukan saja dalam memasarkan partai politik beserta program dan visinya.

Gerakan sabilulungan raksa desa yang dilakukan Dadang Naser bersama timnya, merupakan upaya pencitraan sekaligus kalau meminjam pendapatnya Dan Nimmo dalam Komunikasi Politik: Komunikator, Pesan dan Media bahwa gerakan sabilulungan raksa desa itu bagian dari realitas politik yang disampaikan melalui lambang yang signifikan (2005:114).

Lebih lanjut pendapat Dan Nimmo bisa dijadikan alat untuk mempotret fenomena gerakan sabilulungan raksa desa di Kabupaten Bandung. Menurut Nimmo bahwa politik adalah kegiatan simbolik yang menyentuh sejumlah besar orang, karena orang-orang menemukan makna dalam penggunaan lambang, pembuatan lambang, dan penyalahgunaan lambang pada komunikator politik. Singkatnya melalui politik pemerintah menetapkan dan mendekritkan sebagian dari moral publik (2005: 114). Merujuk pada gagasan Nimmo ini, bahwa sabilulungan raksa desa merupakan 
bagian dari aktivitas atau realitas politik yang dilakukan Dadang Naser.

Dadang Naser yang dipilih langsung oleh masyarakat Kabupaten Bandung, dan memenangkannya untuk dua periode, sebagai bukti kalau Dadang Naser telah terjadi komunikasi politik di wilayah Kabupaten Bandung. Dan di antara kunci keberhasilan politiknya, Dadang Naser bisa menghadirkan sesuatu yang baru dan berbeda, namun tidak lupa tema-tema lokal yang sesuai dengan potensi dan masalah yang dihadapi masyarakat Kabupaten Bandung, yaitu jawabannya pada gerakan sabilulungan raksa desa.

Berbeda dengan beberapa pendapat di atas, bahwa gerakan sabilulungan raksa desa yang dilakukan Dadang Naser dan tim relawan di Kabupaten Bandung bisa dikatakan sebagai iklan politik. Bahkan iklan politiknya dilakukan ketika masa-masa kampanye, dan berlanjut pada pemerintahannya di Kabupaten Bandung, bisa dilihat pada penjelasan Robert Baukus (dalam Cangara, 2016:305) yang membagi iklan politik atas empat macam, yakni:

1. Iklan serangan, yang ditujukan untuk mendiskreditkan lawan. Dadang Naser dan tim relawan sabilulungan secara tidak disadari membicarakan kekurangan dan kelemahan yang dimiliki lawan politiknya dalam pilkada Kabupaten Bandung kepada konstituen dan para pendukungnya, dengan harapan orang semakin tahu akan ketidaklayakan lawan politiknya dalam Pilkada;

2. Iklan argumen, yang memperlihatkan kemampuan para kandidat untuk mengatasi masalah-masalah yang mereka hadapi. Dadang Naser dan tim relawan seringkali membuat statement, baik ketika sedang diwawancara media, atau ketika berpidato memberi sambutan mengklaim akan kemampuan, keberhasilan, dan prestasi-prestasi yang pernah dicapainya selama satu periode memimpin Kabupaten Bandung;

3. Iklan ID, yang memberi pemahaman mengenai siapa sang kandidat kepada para pemilih. Tim relawan sabilulungan secara aktif dan intensif terus menyebarkan informasi dan isu-isu kalau Dadang Naser merupakan kandidat terkuat pada Pilkada Kabupaten Bandung dengan spanduk dan baligho di pinggirpinggir jalan dan tempat-tempat strategis;

4. Iklan resolusi, di mana para kandidat menyimpulkan pemikiran mereka untuk para pemilih. Dadang Naser dan tim relawan dalam iklan politiknya senantiasa menyebutkan keberhasilan program sabilulungan pada periode pertamanya memimpin Kabupaten Bandung, seperti program rutilahu yang berhasil mengentaskan rumah tidak layak huni.

Dadang Naser dan tim rewalannya melakukan keempat iklan politik mulai kampanye sampai sekarang. Meskipun sekarang bukan lagi masa-masa kampanye, tetapi tetap saja lawan politik masih tetap terus berjuang menunjukkan perlawanannya. Bisa dilihat di legislatif dan di masyarakat. Kemudian iklan argument sekarang terus dilakukan oleh Dadang Naser dan tim relawan, yang menunjukkan kalau program sekarang bisa mengatasi masalah yang dihadapi masyarakat Kabupaten Bandung. Dan iklan ID tetap dilakukan meskipun dalam konteks yang lain, yaitu menunjukkan kalau Dadang Naser memang pantas dan layak memimpin Kabupaten Bandung untuk periode keduanya. Dan terakhir 
adalah iklan resolusi, Dadang Naser terus mensosialisasikan pemikiran intinya dari sabilulungan raksa desa yang semuanya adalah untuk rakyat.

Ada beragam iklan politik yang dilakukan Dadang Naser beserta tim relawannya. Berdasarkan pantauan di lapangan terlihat ada beberapa sabilulungan tertera di beberapa tempat yang kelihatan sudah lama, seperti di gapura, spanduk di beberapa tempat strategis, tulisan-tulisan sabilulungan di tempat-tempat publik. Termasuk juga di website Kabupaten Bandung dan beberapa atribut yang digunakan masyarakat, seperti kaos, topi dan lain sebagainya. Itu semua menandakan kalau istilah sabilulungan sudah lama dipakai di masyarakat Kabupaten Bandung.

Media-media yang digunakan Dadang Naser dan tim relawan adalah media iklan politik seperti yang dikatakan Cangara (2016:304) bahwa media-media seperti pamflet, poster, surat kabar dan pertunjukanpertunjukan publik, misalnya parade dan pawai digunakan sebagai iklan politik. Isinya mengajak orang untuk melakukan apa yang diharapkan pengiklan.

\section{Kendala Komunikasi Politik Sabilulungan Raksa Desa}

Kendala dalam pelaksanaan program sabilulungan raksa desa di Kabupaten Bandung, dari internal pemerintahan sendiri dan eksternal pemerintah. Internal pemerintah berada di beberapa dinas dan legislatif atau orang partai politik. Sementara kendala dari eksternal yaitu di luar pemerintahan (eksekutif dan legislatif), seperti masyarakat, organisasi massa, dan beberapa instansi pendukung pemerintah dalam menjalankan tugastugasnya.
Kendala-kendala inilah yang mengakibatkan program, prinsip dan filosofi sabilulungan raksa desa yang sudah bagus tidak bisa terlaksana dengan baik di lapangan. Akhirnya ada pencapaian atau target pemerintah Kabupaten Bandung tidak semuanya bisa terealisasi dengan baik. Berikut beberapa paparan mengenai kendalakendala yang terjadi di Kabupaten Bandung dalam implementasi sabilulungan raksa desa. Misalnya yang dikatakan informan berikut ini, bahwa kendala dalam merealisasikan sabilulungan raksa desa ialah adanya resistensi secara politik dari lawan politik atau pihak oposisi di legislatif.

Penentangan-penentangan

terhadap program pemerintah Dadang Naser, dalam mewujudkan sabilulungan raksa desa, tindakan itu karena istilah atau program ini dibuat ketika Dadang Naser sebelum menjadi Bupati, tepatnya sebagai calon dan sabilulungan menjadi tagline untuk tim kampanye atau tim relawannya. Muncul ketidaksukaan ketika menang dan menjadi bupati, istilah ini akhirnya masuk pada pemerintahan.

Bentuk penentangan lain hadir dari partai politik di legislatif secara tidak langsung, tetapi nampak dalam pembentukan peraturan daerah, kebijakan yang sebelum disosialisasikan dibahas dulu di legislatif. Penentangan dan perlawanan dari orang berseberangan partai politik di legislatif, telah menghambat program yang akan dilakukan pemerintahan Dadang Naser.

Program-program yang seharusnya segera dibuat dan dieksekuti di lapangan, karena masyarakat membutuhkannya, tetapi menjadi lambat dan tidak bisa diatasi karena di legislatif masih saja berkutat kepentingan golongan. Lebih dari itu, 
adanya upaya ingin menjatuhkan popularitas rezim yang sedang berkuasa, dalam hal ini Dadang Naser.

Selain dari kendala yang boleh dikatakan faktor politik. Kendala juga bisa dikategorikan dari faktor sosial. Sudah dua periode berjalan sabilulungan digulirkan tetapi belum benar-benar dipahami oleh masyarakat luas di Kabupaten Bandung. Hal itu terbukti dari tingkat pemahaman sampai apresiasi masyarakat atas program dan isi dari sabilulungan.

Berdasarkan pengamatan peneliti di lapangan, masih ada kesan kuat kalau sabilulungan ini masih tagline tim kampanye Dadang Naser dan Gugun. Sebagian besar masyarakat, belum memahami dan mengetahui kalau sabilulungan ini moto kerja pemerintahan Dadang Naser. Terlebih dengan moto kerja pada periode kedua Dadang Naser yang ditambahkan menjadi sabilulungan raksa desa. Sehingga tidak heran kalau masyarakat masih acuh tak acuh dengan sabilulungan.

Sikap acuh ini atas persoalan efek dari pemilihan bupati yang masih membekas. Di antara kalangan yang calon bupati yang kalah dalam pemilihan tidak serta langsung melupakan kekahalan, dan langsung mendukung terhadap program bupati terpilih. Tetapi masih ada saja di antara masyarakat yang sakit hati terus melakukan upaya-upaya agar Dadang Naser gagal dalam menjalankan tugasnya sebagai bupati pada periode kedua. Terbukti di lapangan ada sebagian masyarakat yang apatis dan selalu mementingkan kepentingan pribadi yang ingin dipenuhi. Tidak peduli dengan siapa bupati dan program apa, yang penting kebutuhan-kebutuhan pribadinya terpenuhi.
Kendala di kalangan pemerintahan atau pejabat, mulai dari kadis sampai staf yang berada di lingkungan pemerintahan Kabupaten Bandung pun mirisnya tidak jauh berbeda dengan kondisi di lapangan masyarakat. Masih ada para pejabat sampai tingkat staf di Kabupaten Bandung yang tidak memahami apa itu sabilulungan, termasuk hakekat dari sabilulungan. Bagaimana mau bisa dilaksanakan dan terimplementasi dengan baik kalau sabilulungan sendiri tidak paham.

Lebih salahnya lagi para pejabat dan staf ini melakukan tugas dan kinerjanya yang berorientasi sabilulungan sebatas ritual atau seremoni semata. Ini dilakukan karena bertujuan menyenangkan Bupati Dadang Naser. Padahal dibalik itu tidak tahu apa sesungguhnya sabilulungan itu. Seperti yang dikatakan relawan Sabilulungan, Indra Subhan: "Kendala yang terjadi hari ini yang paling berat. Orang tahu tentang sabilulungan, tapi tidak melaksanakannya dan sebagian di birokrat pemerintahan. Sabililungan baru sebatas cangkang belum isi, baru sebatas ceremoni. Di birokrat baru sebatas seremoni, karena ingin kapuji bupati"

Tidak heran kalau program dan target sabilulungan tidak dengan cepat terlaksana karena selain lemahnya atau kurangnya masyarakat dan birokrat memahami sabilulungan, juga karena pemahaman yang salah masyarakat terhadap sabilulungan. Terutama sabilulungan raksa desa. Idealnya pada periode kedua pemerintahan Dadang Naser, pembangunan sudah tidak lagi pada pembangunan fisik, tetapi fokus pembangunan non fisik yaitu manusianya. Harapannya dengan sabilulungan ini, pembangunan manusia (mental, spiritual, dan motivasi) 
terlaksana dengan baik, kendala lainnya terkait minimnya dukungan anggaran.

Pemerintahan Dadang Naser mengalami masa sulit ketika mengajukan program-program kepada anggota dewan, termasuk ketika membuat Peraturan Daerah di Kabupaten Bandung, karena ketika proses pengajuan di legislatif, Dadang Naser harus bekerja keras memperjuangkannya dari partai politik yang nota bene menjadi rival Dadang Naser. Ini menjadi kendala yang serius dalam mengimplementasikan sabilulungan raksa desa. Meskipun Dadang Naser berangkat dari independen ketika maju pada pemilihan bupati untuk kedua kalinya, namun tetap saja partai lain tidak bisa mengakui independensi Dadang Naser. Partai-partai politik yang menjadi rival tetap mengklaim kalau Dadang Naser adalah orang Partai Golongan Karya.

Kondisi ini sesuai dengan data yang menyatakan bahwa pada Pilkada serentak tahun 2015 ada 139 dari 829 pasangan calon maju dengan jalur perorangan (dalam Cangara, 2016: 223). Para calon perorangan ini merasa memiliki kapabilitas dan pengaruh yang besar terhadap para pemilih. Mereka tidak mau menggunakan jalur partai politik dengan pertimbangan; selain sulitnya memperoleh dukungan dari partai politik yang mengalami konflik internal, susah menentukan kepengurusan mana yang sah pada partai golkar dan PPP, juga mereka menilai bahwa menggunakan jalur perorangan lebih murah dan efisien, karena tidak memerlukan uang mahar untuk meminang agar partai politik ikut mengusung pencalonannya, dan lebih efisien dengan hanya mengumpul kartu penduduk yang bisa dilakukan oleh tim sukses masing-masing (Cangara, 2016: 223).
Apa yang dilakukan partai politik yang berbeda pandangan dalam membuat kebijakan pemerintah Kabupaten Bandung di dalam legislatif, sudah sesuai dengan tugas dan kewajiban partai politik sebagaimana tercantum dalam Undang-undang Nomor 2 tahun 2008 pasal 13, terutama ayat 2, 3, dan 4 yaitu: Memelihara dan mempertahankan keutuhan Negara Kesatuan Republik Indonesia; Berpartisipasi dalam pembangunan nasional; Menjunjung tinggi supremasi hukum, demokrasi, dan hak asasi manusia.

Pasca Pilkada di Kabupaten Bandung sama sekali tidak ada kerusuhan, tidak ada konflik horizontal di antara simpatisan dan partai politik yang berkepanjangan, sehingga tetap terpelihara keutuhan NKRI. Kemudian partai politik juga berpartisipasi dalam pembangunan di Kabupaten Bandung tinggal bagaimana terjadinya dinamika demokrasi di dalam legislatif, sehingga program-program yang diajukan pemerintahan Dadang Naser baik dan lebih bagus dari sebelum-sebelumnya.

Dukungan dari partai politik yang kurang terhadap program sabilulungan raksa desa di level legislatif dan partai politik, secara tidak langsung partai politik ini melanggar tiga prinsip sebagai dasar dari partai politik, yaitu (Cangara, 2016: 168-169):

1. Partai sebagai koalisi, yakni membentuk koalisi dari berbagai kepentingan untuk membangun kekuatan mayoritas. Partai yang dibentuk atas dasar koalisi di dalamnya terdapat faksi-faksi. Kehadiran faksi-faksi dalam partai besar sering mengacaukan kesatuan partai, karena satu sama lain berusaha menjadi dominan dalam partai. Ketidakcocokan dalam partai terutama muncul dalam hal 
penetapan asas perjuangan, program, kepengurusan organisasi dan pencalonan kandidat;

2. Partai sebagai organisasi, untuk menjadi institusi yang eksis, dinamis dan berkelanjutan partai politik harus diorganisasi. Partai harus dibina dan dibesarkan sehingga mampu menarik dan menjadi wadah perjuangan, dan representasi dari sejumlah orang atau kelompok. Tugasnya mencalonkan anggota untuk pemilu dengan label partai. Mengambil bagian dalam pemilu, mengajukan calon yang disepakati, mengumpul dana, dan membuat isu propaganda dalam kamapnye. Untuk itu partai politik melakukan mobilisasi kepada anggota-anggotanya untuk loyal kepada partai;

3. Partai sebagai pembuat kebijakan (policy making). Partai politik juga berbeda dari kelompok sosial lainnya dalam hal pengambilan kebijakan. Partai politik mendukung secara konkret para calon yang mereka ajukan untuk menduduki jabatanjabatan publik. Dari posisi ini mereka memiliki kekuasan untuk memengaruhi atau mengangkat petugas atau karyawan dalam lingkup kekuasaannya, bahkan turut memberi pengaruh dalam pengambilan kebijakan di kementerian, di mana kader partai menduduki posisi yang sama melalui kolegitas partai.

Melihat ketiga standar sebuah partai politik, posisi dan kedudukan partai sangat signifikan dalam sebuah pemerintahan. Namun tetap saja harus menilai dan melihat sebuah program yang diajukan pemerintah mengedepankan objektivitas. Jangan terus-terusan mengevaluasi, apalagi sampai menghambat. Karena partai politik sangat bisa mengubah sesuatu yang tidak mungkin menjadi mungkin. Partai politik harus bisa membedakan antara gerakan dan kelompok penekan. Gerakan adalah kelompok atau golongan yang ingin mengadakan perubahan, atau menciptakan suatu lembaga masyarakat baru dengan memakai cara-cara politik. Jangan sampai pada praktiknya partai politik terus melakukan gerakan dan menekan tanpa memberikan solusi dan kontribusi yang berarti terhadap perubahanperubahan kea rah yang lebih baik.

Melihat kendala yang dihadapi Dadang Naser dalam melaksanakan sabilulungan raksa desa dari politik dan sosial, artinya kurang adanya partisipasi politik. Karena partisipasi politik bisa dilihat dari dua sisi, yaitu sisi penguasa (pemerintah) dan dari sisi warga negara (Harun dan Sumarno, 2006:133).

Lebih jauh Harun dan Sumarno (2006: 133) menjelaskan bahwa dari sisi pemerintah, hakikat partisipasi politik mengandung makna sebagai pengakuan dan penghargaan kepada masyarakat (warga negara, rakyat) dalam bentuk memberi kesempatan untuk berperan serta memikirkan masalah kehidupan negara, dalam hal hal ini masalahmasalah masyarakat Kabupaten Bandung, melalui kegiatan pemilihan individu-individu yang akan duduk dalam lembaaga-lembaga kekuasaan.

Kurangnya apresiasi politik dari partai politik yang diwakili anggota dewan atau legislatif, karena berbeda partai politik dengan Dadang Naser, dan kurangnya partisipasi masyarakat sehingga program sabilulungan raksa desa tidak bisa maksimal, bisa jadi karena kurangnya pemerintah dalam mengelola sumber-sumber saluran komunikasi, sekaligus melibatkan media massa yang diarahkan untuk: a. Meningkatkan pemahaman, minat warga negara dalam peran serta 
terhadap pelaksanaan seluruh kebijaksanaan pemerintah; b. Menumbuhkan keyakinan warga negara bahwa person serta secara aktif akan memberi manfaat bagi warga negara sendiri; c. Membentuk sikap agar partisipasi tumbuh atas kesadaran warga negara; d. Mengantisipasi agar tidak tumbuh opini negatif sebagai faktor penyebab lesunya partisipasi (Harun dan Sumarno, 2006: 133).

\section{Pengelolaan Media Isu Sabilulungan Raksa Desa di Kabupaten Bandung}

Pengelolaan media isu sabilulungan raksa desa di Kabupaten Bandung sudah memiliki standar aturan dan prinsipprinsip yang berbeda dengan pemerintah lain. Pemerintah Dadang Naser beserta tim relawan sabilulungan tidak memanfaatkan media sosial sebagai media publikasi atas berbagai pencapaian prestasi dan programprogramnya. Termasuk upaya pencitraan diri dan lembaga agar terus meningkatkan kredibilitas di mata konstituennya. Dadang Naser dan tim relawan sabilulungan raksa desa mengalir saja. Tidak ada upaya khusus dan serius dalam mengelola media. Media dibiarkan begitu saja, dan membolehkan beritakan apa adanya tentang apa saja yang sudah dilakukan pemerintahannya.

Dadang Naser memilih natural dalam menggunakan media sosial dalam kampanye dan sosialisasi program Dadang Naser bukan karena tidak melek IT dan lain sebagainya. Tetapi lebih kepada menjaga unsur keaslian dan alami atas berbagai hal yang terjadi dan terkait dengan pemerintah Dadang Naser. Baik pada periode pertama maupun periode kedua. Hal itu terlihat dari tidak adanya tim kreatif media dibalik Dadang Naser yang bertugas mengelola isu-isu aktual.
Namun kalau sekedar bersilaturahmi dan berinteraksi dengan media itu dilakukan secara intensif, minimal satu minggu sekali setiap hari jumat. Tujuannya adalah mendengar berbagai informasi yang didapatkan wartawan, sebagai bahan evaluasi dan membuat program berikutnya pemerintahan Dadang Naser. Selain dengan media dalam rangka menyerap berbagai informasi yang aktual di masyarakat sekitar Kabupaten Bandung dan kejadian di sekitar Jawa Barat.

Pemerintahan Dadang Naser juga secara intensif melakukan komunikasi berupa program "urun rembuk" dalam rangka up date isu-isu agar tidak ketinggalan jauh dengan pemerintahan lainnya bersama perwakilan aktifis partai politik, anggota dewan, tokoh masyarakat bahkan organisasi massa.

Dadang Naser dan tim relawan sabilulungan raksa desa membiarkan isu mengalir dan beredar bebas di tengah-tengah masyarakat. Tidak ada upaya khusus dan serius dalam mengelola media massa. Media massa dibiarkan begitu saja, dan membolehkan memberitakan apa adanya tentang apa saja yang sudah dilakukan Bupati Dadang Naser di Kabupaten Bandung.

Publikasi dan sosialisasi program dan kebijakan dari Pemerintah Kabupaten Bandung lebih menggunakan media konvensional dan cenderung normatif, yaitu media-media yang pada umumnya digunakan oleh para pemerintah seperti spanduk, baligho, banner, dan media-media below the line.

Pemilihan media konvensional disesuaikan dengan kondisi pengetahuan, tingkat pendidikan dan budaya melek media masyarakat Kabupaten Bandung. sebagaimana dikatakan Cangara (2016: 331) bahwa pemilihan media komunikasi harus 
didasarkan pada isi pesan yang ingin disampaikan, dan pemilikan media yang dimiliki khalayak.

Masyarakat Kabupaten Bandung sebagian besar masyarakatnya pedesaan, dengan profesi sebagai petani, peternak, yang kurang mengakses media massa untuk mengikuti perkembanganperkembangan peristiwa atau kejadian yang terjadi sekitar Kabupaten Bandung. Terlebih lagi media sosial yang hanya kalangan tertentu yang menggunakannya, yaitu kalangan anak muda, yang itu pun jarang mengakses kondisi dan situasi yang terjadi di sekitar wilayah Kabupaten Bandung. Inilah salah satu pertimbangan tidak memaksimal media massa dalam diseminasi informasi dan sosialisasi program-program Kabupaten Bandung. Terkecuali targetnya agar tersebar luas ke daerah lain di luar Kabupaten Bandung. Untuk hal ini sesekali ada berita tentang Kabupaten Bandung yang diberitakan di media, dengan jangkauan dan segmen pembacanya lebih luas, seperti Pikiran Rakyat, Tribun Jabar dan lain sebagainya.

Media memang bisa menjadikan para politisi sebagai pembuat berita (newsmaker). Dalam hal ini, melalui media masyarakat Kabupaten Bandung bisa mengetahui dan memahami program sabilulungan raksa desa. Bahkan anak-anak juga bisa banyak mengetahui tentang aktifitas politik dan pembangunan di pemerintah Kabupaten Bandung yang di ekspose oleh media.

Rebecca (1979) memperkuat pentingnya menggunakan media dalam memperkenalkan sebuah program atau kebijakan. Dia melihatnya pada seorang claon, bahwa liputan yang dilakukan secara terus menerus oleh media cukup akurat untuk meningkatkan pengetahuan pemilih pada calon.
Seorang pemilih yang mengetahui banyak tentang calon, besar kemungkinan akan memilihnya daripada calon yang mereka tidak ketahui. Para pemilih umumnya mengaku lebih banyak tahu tentang calon yang mereka idolakan melalui media. Jika dua ribu tahun yang lalu orang-orang Yunani mengatakan bahwa keberhasilan seorang pemimpin sangat ditentukan oleh karakter dan etos, maka sekarang harus ditambah dengan kemampuan dalam menguasai media (dalam Nimmo, 2005: 45).

Sementara Graber (1984:10) menunjukkan salah satu fungsi media massa dalam sistem politik yakni sebagai media sosialisasi politik (political socialization). Dan Asep Saeful Muhtadi (2008:46) mengatakan bahwa media massa melakukan proses pembelajaran tentang orientasi dan nilai-nilai dasar kepada individu dalam memahami llingkungan kulturalnya. Bahkan media juga bisa dipandang sebagai instrument ideologi. Melalui media suatu kelompok menyebarkan pengaruh dan dominasinya kepada kelompok lain. Termasuk kelompok dari tim relawan sabilulungan raksa desa yang bisa mempengaruhi kelompok lain.

Tim relawan sabilulungan raksa desa tidak hanya memilih media konvensional dan normatif, juga tidak menggunakan media sosial yang sedang ramai dipakai masyarakat. Sementara di daerah-daerah lain, pihak pemerintahan sudah ramai menggunakan media sosial sebagai media publikasi dan sosialisasi program dan kebijakan-kebijakan pemerintah.

Kalau melihat pada jumlah pengguna internet tertinggi di dunia, Indonesia menempati peringkat ke-6 setelah ina, AS, India, Jepang dan Brazilia. Dari sisi presentasi penetrasi, 
rata-rata pengguna dengan jumlah penduduk suatu negara untuk kawasan Asia Tenggara Indonesia memang tertinggi jumlah penggunaannya. Artinya kalau pemerintah Kabupaten Bandung melihat fenomena ini, dan menyadari kalau masyarakat sekarang telah gandrung dengan media sosial, maka penggunaan media sosial sebagai media publikasi dan sosialisasi pemerintah Kabupaten Bandung akan lebih efektif dan tepat. Lebih-lebih dekat dengan masyarakatnya.

Selain itu, media sosial atau media internet, memiliki sejumlah kalebihan, antara lain: (1) kemampuan untuk menembus batas wilayah, ruang dan waktu; (2) memperluas akses memperoleh informasi global; (3) meningkatkan kemmapuan untuk berserikat secara bebas; (4) mengancam tatanan yang telah mapan, seperti pemerintahan otokrasi, serta (5) memiliki kecepatan perkembangan dan penyebaran yang sulit diatasi (Cangara, 2016: 351).

Meskipun membiarkan media melakukan pemberitaan tentang Kabupaten Bandung apa adanya, dan tidak ada pengelolaan isu-isu di media sampai agenda setting terhadap media massa, tetapi kedekatan dengan media dan rutinitas berkumpul dengan media tetap dilakukan Dadang Naser. Hal ini bertujuan untuk mendapatkan informasi sebanyak-banyak mengenai isu-isu yang berkembang di masyarakat, daerah lain baik kota ataupun kabupaten yang bisa diadopsi ide dan programnya di Kabupaten Bandung.

Dadang Naser seperti halnya para pemimpin pada umumnya, memiliki humas untuk menjaga hubungan yang baik dengan media. Dan hal ini adalah lumrah untuk seorang pemimpin atau politisi yang biasanya menunjuk juru bicara atau biasa disebut press secretary yang berfungsi sebagai public relations. Petugas humas di pemerintahan Kabupaten Bandung inilah yang menjembatani antara pimpinan termasuk Bupati Dadang Naser dengan para wartawan. Humas di Kabupaten Bandung memahami Dadang Naser, sejarah dan latar belakang kehidupan dan mampu membaca pikiranpikirannya, mengatur jadwal interview dan konferensi pers, membuat laporan singkat kegiatan dan menjadi perisai dari kejaran wartawan.

Sebagaimana dikatakan Rusadi Ruslan bahwa seorang humas di sebuah instansi atau lembaga pemerintah, selain berperan sebagai komunikator, juga berperan sebagai manajer berita. Hampir semua kegiatannya yang paling utama adalah bagaimana menciptakan publikasi melalui konferensi pers untuk mengundang wartawan agar bisa menyiarkan informasi yang perlu disampaikan kepada khalayak, termasuk mengadakan press tour secara on the spot untuk melihat secara langsung tentang aktivitas atau kegiatan di lapangan (Ruslan, 1997: 52). Seperti ketika Dadang Naser meresmikan sebuah gedung, jalan, kunjungan kerja ke daerah pertanian, perkebunan, peternakan atau tempat wisata. Bagaimana pernyataan dan foto-foto Dadang Naser dikondisikan agar pantas dan layak pernyataan dan tampilannya di media massa, baik media massa lokal maupun regional.

Adapun mengenai kemampuan humas dalam menciptakan berita atau informasi dalam bentuk tulis menulis (news writing skill) dalam pembuatan press release, news letter, in house journal. Artinya sebagian besar peranan praktisi humas merupakan kegiatan utama sekitar $75 \%$ seorang humas adalah tulis menulis, menjadi sumber berita (source of news) dalam upaya 
merekayasa suatu berita demi kepentingan publikasi yang menguntungkan citra lembaga atau institusi yang diwakilinya (Ruslan, 1997: 52). Hal ini humas Kabupaten Bandung nampaknya belum memenuhi semuanya. Kompetensi dan wawasannya belum mencapai pada upaya pembentukan press release untuk kegiatan bupati dan dinas-dinas pemerintahan yang bisa dijadikan bahan berita oleh media.

Kalau sekedar membina hubungan baik dengan pers atau media (press and media relations) sudah bisa melaksanakan tugasnya dengan baik. Setiap minggu media diundang untuk sharing informasi yang bisa dijadikan trigger bupati dan pejabat di Kabupaten Bandung. Media-media lokal, regional, dan nasional senantiasa hadir pada perkumpulan rutin setiap hari Jum'at untuk melaksanakan sosialisasi pembangunan pada lingkungan pemerintah daerah.

Komunikasi politik sabilulungan raksa desa yang menjadi komunikatornya adalah Dadang Naser dan tim relawan sabilulungan raksa desa. Dadang Naser dan tim sabilulungan seringkali membuat pesanpesan yang terangkum dalam sabilulungan raksa desa. Programprogram inti sabilulungan raksa desa yaitu rutilahu, air, kakus, sampah dan alam melalui media disebarkan ke masyarakat luas. Adapun media yang digunakan untuk publikasi dan sosialisasi program sabilulungan raksa desa ialah ada dua media, yaitu media yang masuk kategori below the line seperti selebaran brosur dan famplet, baligho, dan spanduk yang beredar di sekitar perkantoran, jalan, dan tempattempat strategis. Dan untuk menjangkau yang lebih luas menggunakan media yang masuk kategori above the line seperti yaitu media massa (cetak dan elektronik).

Pesan-pesan ini ditujukan secara khusus pada masyarakat Kabupaten Bandung dan pemerintah, yaitu dinasdinas yang berada di bawah Bupati Dadang Naser agar bisa melaksanakan program sabilulungan raksa desa. Adapun pemerintah diharapkan selain mengetahui, memahami dan menjalankan program sabilulungan raksa desa di Kabupaten Bandung, sehingga terjalin kerjasama yang sinergi antara unsur eksekutif, legislatif dan masyarakat.

Terakhir adalah efek dari pesan tersebut yang diharapkan terjadi percepatan pembangunan di Kabupaten Bandung. efek ini akan langsung ditangkap oleh komunikator yaitu Dadang Naser dan tim relawan sabilulungan raksa desa. Tindakan di akomodirnya program tersebut, dikarenakan Dadang Naser dan tim relawan ini aktif turun ke masyarakat untuk melihat seberapa besar permasalahan dan kondisi di lapangan. Efek dari pesan ini tidak hanya didapatkan dari masyarakat langsung, tetapi juga didapatkan dari partai politik yang pro terhadap kepemimpinan Dadang Naser, sehingga benar-benar informasi didapatkan dari kedua belah pihak.

\section{Simpulan}

Berdasarkan pembahasan diatas maka kesimpulannya pertama gerakan sabilulungan raksa desa ini merupakan filosofi, prinsip dan motto bupati serta pemerintah Kabupaten Bandung dalam mengemban amanah, dengan tujuan agar di Kabupaten Bandung tumbuh semangat kebersamaan, gotong royong, dan hidup beriringan dalam kehidupan sehari-hari. Ada lima sasaran yang menjadi inti dari gerakan sabilulungan 
raksa desa, yaitu rutilahu, air, kakus, sampah, dan alam; kedua Implementasikan sabilulungan raksa desa, Bupati Dadang Naser dan tim relawaanya mendapatkan tiga kendala, yaitu: pertama, Kendala politik. Bupati Dadang Naser senantiasa mendapatkan resistensi dan hambatan-hambatan komunikasi politik dengan partai politik dan anggota legislatif di tingkat DPRD, ketika membuat Peraturan daerah yang mendukung setiap program-program atau kebijakan bupati dan pemeritah hingga sehebat apapun programnya menjadi lambat implementasinya di lapangan. Kedua, kendala sosial. Adapun kendala sosial ialah lemahnya support dari arus bawah, yaitu masyarakat luas Kabupaten Bandung. pengetahuan dan wawasan masyarakat mengenai prinsip dan filosofi sabilulungan raksa desa masih lemah. Masih banyak masyarakat yang tidak mengetahui apa makna dan tujuan dibalik sabilulungan raksa desa. Kendala lainnya adalah budaya. Masih banyaknya budaya-budaya para pejabat di Kabupaten Bandung yang ingin dinilai bagus dan mendapat apresiasi dari Bupati Dadang Naser ketika membuat acara, program yang berbau sabilulungan raksa desa, sementara kontribusi dan dampaknya sama sekali tidak terasa. Masih banyak kegiatankegiatan di dinas dan masyarakat yang bertemakan sabilulungan raksa desa sebatas ritual dan seremonial semata; ketiga Pemerintah Kabupaten Bandung yang dipimpin oleh Dadang Naser beserta tim relawan sabilulungan raksa desa, dalam menggunaan atau memanfaatkan dan mengelola media isu masih tergolong konvensional dan normatif. Tidak memiliki tradisi dalam mengelola sebuah media isu, terlebih lagi memanfaatkan media sosial sebagai media publikasi untuk sosialisasi program, rencana pembangunan, dan publikasi atas berbagai pencapaian prestasi, penghargaan yang telah diraih Kabupaten Bandung. Termasuk upaya pencitraan diri dan lembaga agar kredibilitasnya meningkat di masyarakat.

\section{DAFTAR PUSTAKA} Communication Theories, Epistemological Foundations. London : The Guilford Press.

Arifin. 2006. Pencitraan Dalam Politik: Strategi Pemenangan Pemilu Dalam Perspektif Komunikasi Politik. Jakarta: Rajawali Press.

Bungin, Burhan. 2001. Imaji Media Massa. Yogyakarta: Jendela.

Budiardjo. 2002. Dasar-Dasar Ilmu Politik: Jakarta: Gramedia Pustaka Utama.

Cangara, Hafied. 2016. Komunikasi Politik: Konsep, Teori, dan Strategi. Cet. Ke-5. Jakarta: Rajawali Press.

Creswell, John W. 1998. Qualitative Inquiry and Research Design. California : Sage.

DeVito, Joseph A. 2006. Human Communication. The Basic Course. USA : Pearson Education. Inc.

Firmanzah. 2011. Persaingan, Legitimasi Kekuasaan, dan Marketing Politik. Jakarta: Rajawali Press.

Firmansyah. 2008. Marketing Politik: Antara Pemahaman dan Realitas. Jakarta : Yayasan Obor Indonesia.

Fisher, B. Aubrey. 1986. Teori-Teori Komunikasi. Bandung : Remaja Rosdakarya.

Garna, Judistira K. 1999. Metode Penelitian: Pendekatan Kualitatif. Bandung : Primaco Akademika. 
Graber, Doris A. 1984. Massa Media and American Politics. Washington DC: CQ Press.

Harun, Rochajat dan Sumarno AP. 2006. Komunikasi Politik sebagai Suatu Pengantar. Bandung: Mandar Maju.

Littlejohn, Stephen W. and Foss, Karen A. 2008. Theories of Human Communication. USA: Thonson Wadsworth.

Moleong, Lexy J. 2000. Metode Penelitian Kualitatif Edisi Revisi. Bandung : Remaja Rosdakarya.

Muhtadi, Asep Saeful. 2008. Komunikasi Politik Indonesia: Dinamika Islam Politik Pasca Orde Baru. Bandung: Remaja Rosdakarya.

Nimmo, Dan. 2005. Komunikasi Politik: Komunikator, Pesan, dan Media. Bandung: Remaja Rosdakarya.

Rakhmat, Jalaluddin, 2001. Psikologi Komunikasi. Bandung : Remaja Rosdakarya.

Ruslan, Rosady. 1997. Kiat dan Strategi Kampanye Public Relations. Jakarta: Rajawali Pers.

Salim, Agus. 2006. Teori dan Paradigma Penelitian Sosial : Buku Sumber Untuk Penelitian Kualitatif. Jakarta : Tiara Wacana.

Sungkawa, Dadan. 2013. Spirit Sabilulungan: Dina Gulidag Budaya Global. Bandung: Palwa.

Tabroni, Roni. 2012. Komunikasi Politik Pada Era Multimedia. Bandung : Remaja Rosdakarya.

Venus, Antar. 2007. Manajemen Kampanye. Bandung: Simbiosa Rekatama.

Yanto, Strategi Kampanye Politik Calon Anggota Legislatif Incumbent Dewan Perwakilan Rakyat Daerah Dalam Menghadapi Pemilu Legislatif
2014: Studi Kasus Partai Golkar

Di Kabupaten Mukomuko. Jurnal Professional FISUNIVED Vol.1 No.2 Desember 2014, hal. 61-72.

\section{Biodata Penulis}

Vera Hermawan S.I.Kom., M.I.Kom., lahir di kabupaten Subang, 15 Februari 1985, menyelesaikan studi sarjananya di Ilmu Komunikasi FISIP Universitas Pasundan dan melanjutkan studinya pada jenjang magister Ilmu Komunikasi dan Media FIKOM Universitas Padjadjaran. Aktifitasnya kini sebagai Akademisi pada kampus Almamaternya Ilmu Komunikasi FISIP Universitas Pasundan. Selain mengabdikan diri sebagai akademisi, juga diberikan amanah menjadi Ketua tim penyunting Jurnal Linimasa, bahkan menjadi narasumber dalam forum-forum kebangsaan, "Menjaga Pancasila dan Merawat Kebhinekaan" yang di gagas oleh Badan Pembinaan Ideologi Pancasila (BPIP) RI dan Kemenkominfo RI. Fokus kajiannya dalam melaksanakan penelitian Ilmu Komunikasi dan Politik, akhirnya melahirkan beberapa lembaga diantaranya, Indonesian Communication Research (ICR), Karyanya "Potret Siaran Televisi di Jabar" KPID Jabar 2016 dan Pusat Kajian Politik dan Demokrasi (Puskapoldem) FISIP Universitas Pasundan. 